\title{
Primary Peritoneal Transitional Cell Carcinoma
}

National Cancer Institute

\section{Source}

National Cancer Institute. Primary Peritoneal Transitional Cell Carcinoma. NCI Thesaurus.

Code C162564.

An extremely rare transitional cell carcinoma that arises from the peritoneum. 